\title{
The Aura of the Analogue in a Digital Age \\ Women's Crafts, Creative Markets and Home-Based Labour After Etsy
}

\author{
SUSAN LUCKMAN \\ UNIVERSITY OF SOUTH AUSTRALIA
}

At a time when the success of the Etsy website and the Cath Kidston label (among others) marks out a space where women's home-based crafts practice is elevated from the local market to the high street, this article examines the renewed popularity of the handmade and of craft production and its relation to economies of amateur labour. ${ }^{1}$ The article situates the popularity of the handmade original as a desirable aesthetic object and part of a broader return of credibility to previously disparaged women's craft practices. This credibility has occurred via younger consumers as well as through the increased potential the internet has created for small-scale business models, where amateur producers with no formal training can set up a creative business. The focus here is on the Etsy.com online marketplace and its spin-off physical markets, and on those practices employing yarn (for example knitting, crochet, needlepoint and weaving) and fabric (sewing, felting). The article then critically examines the economic, political, technological, social and cultural affordances that have enabled this re-articulation of (largely) women's domestic work. I locate current debates around home-based craft production and creative 
work historically by turning attention to the nineteenth-century British Arts and Crafts movement, and its longstanding association with progressive labour practices and small-scale production. Finally, the article considers the claims to radicalism made on behalf of design-craft or indie craft scenes after Etsy about the desirability of the homemade and small-scale production models.

It may seem incongruous, but much of my recent thinking around the contemporary popularity of the handmade really came into focus in the most digital of contexts. For almost half a decade I have run my games studies course with one week of workshop activities focused on participants coming up with a game concept in two hours and then presenting a 10-minute concept pitch to the whole group. The participants work in teams, broken up into various roles based on industry practice: producer, marketing manager, game designer (lead), level designer, art director (lead), 3d/2d artist, animator, technical director (lead), AI/physics programmer, sound engineer, writer and so forth. With time at a premium and the activity taking place in a computer lab, for the last four or so years before 2011 the 'art director' and their team have logically sought inspiration and imagery for the pitch presentation online; cutting and pasting existing material from the internet that matched their own vision into the pitch PowerPoint.

In 2011 something curious occurred. In all classes the 'art director' hand drew the concept artwork for their team. There had been absolutely no change in the framing of the activity given to the students; rather the shift was in them. After years of enacting the 'digital revolution', this year's cohort defaulted to manifesting their creative ideas directly from their mind to the page via their hand and a pencil. Not a single person had done this before, and now they all had. This incident coincided with a period in my own life where I found myself looking out for good deals on film for an old-school Polaroid instant camera because of my teenage stepdaughter's interest in analogue photography. This particular retro technology valuably combines the instantaneity of the digital photo (taken for granted by generations unaccustomed to waiting for their holiday snaps to be developed) with the material artefact of the actual photo. When you are a 'digital native', analogue is new. 
-THE DEMAND FOR HANDMADE CRAFTS AS A MARKER OF INDUSTRIAL AND CULTURAL CHANGE

Networking and dissemination online have played a vital role in the renaissance of craft practice and it would be foolish not to acknowledge this up-front and centrebut I also feel the digital realm is only part of the story here. This fashion cycle is enabled by digital enabling technology, but it fetishises the material, the tactile, the analogue. In the digital age, almost seventy years since the Frankfurt School first railed against the 'culture industry's' commodification and standardisation of all art, the analogue becomes Othered, different, desirable. ${ }^{2}$ This is particularly true of the handmade which is marked by its solid oneness in the world. Perhaps the irony of the return of the analogue in the digital age is evidence of Tonya Jameson's observation that 'Creating something with our hands gives us a false sense of control at a time when we have little'. ${ }^{3}$ Or of Fiona Hackney's proposition that the popularity of craft in the media 'may be read as a means of addressing the problems and anxieties surrounding the acceleration of modern life (unemployment, the strain of new work processes and their effects on physical and mental life)'. ${ }^{4}$ In this way, the renaissance in the handmade at a time of profound social, cultural and economic change in the global West-the 'digital revolution'-has parallels with similar responses to the Industrial Revolution.

At the turn of nineteenth century, the British Arts and Crafts movement and its revival of traditional, especially rural, crafts, was a direct response to the increased mechanisation of production during the Industrial Revolution, and the alienated labour and mass-manufactured products to which it gave rise. 5 The Arts and Crafts movement mobilised traditional crafts practices in the service of a Victorian reforming zeal concerned with the welfare of the worker. This is perhaps best exemplified in architect and writer C.R. Ashbee's famous craft-based social and economic experiment: moving the Guild of Handicraft from the urban squalor of London's East End to the idyllic rural town of Chipping Campden in the Cotswolds. Here, it was hoped, 'the labourers of Britain, stunted in the city, would, in a new setting of dignity and harmony, develop their creative instincts to the fullest'.6 The experiment promised a better life for guild members, for their families and the wider community as the guild operated as an organisational focus not only for craft production but for social and sports activities, general education and training for local children and adults, and town regeneration (with traditional craft skills at the 
forefront of renovation). ${ }^{7}$ Other key figures in the Arts and Crafts movement included artists, commentators, essayists and entrepreneurs such as John Ruskin, William Morris, Marian Twelves, and Hardwicke and Edith Rawnsley. The movement looked backwards to medievalism and traditional artisan crafts for its aesthetic, but it was largely forward thinking in its social outlook. It was at once influenced by socialism, albeit with a strong paternalistic focus on education and welfare as tools for 'reforming' the working class (that is, making them more like the middle classes), and also by the nascent women's suffrage movement, which saw a few women emerge as key players in the Arts and Craft movement, although in general women were relegated to the practical application of the ideas publicly espoused by the heroic figure of the Victorian man. ${ }^{8}$

Continuing on the rural emphasis of arts and crafts initiatives, the English Lake District also saw the development of various arts and crafts industries, in no small part a result of the influence of John Ruskin who spent much time in the region in his house, Brantwood, on Coniston Water. Women's crafts, especially those tied to the local wool industry, featured here more prominently than in Ashbee's Cotswold Guild. Today the most notable, and expensive, products of this period of creativity in the Lake District may be the metalwork of the Keswick School of Industrial Arts, produced largely by men, but crafts traditionally produced by women-lacework, spinning, knitting, linen production-also played a key role in the local creative economy. The emphasis on reform in the various initiatives by middle-class women was evident here as spinning was preferred to knitting. ${ }^{9}$ The mobility of the latter allowed women to gather together and talk while producing, an affordance of knitting explicitly valued by indie craft women today but in previous times associated with feminine distraction. ${ }^{10}$

Further, and in a fashion that replicates contemporary rural anxieties about the loss of people to the cities, a return to local craft production for both sexes was seen as a means to keep people on the land and in their homes in the face of the demand for labour in the great industrial powerhouses of North England such as Manchester, Bradford and Sheffield. Demand for the more expensive, small-scale, wool-based products of the locals had dropped with competition from cheaper manufactured goods. The loss of additional household income proved a tipping point for many. The Arts and Crafts movement as manifest in the Lake District sought to turn this 
process around through the value-adding of creative hand labour. Through the pioneering (and reforming) energies of Marian Twelves and others, local women's textile skills served as the basis for a homework-based local economic revival:

all who were willing among the older and needier of the neighbourhood should come down to a pretty little cottage by Elterwater tarn that had stood in its simple peace beside the laughing streamlet from the fell, for more than two hundred years. This, in memory of the clothing of the destitute by the good Saint of Amiens, was appropriately called 'St. Martin's', and there they should learn again the art of spinning. Thence, having so learned it, they should take the wheels to their cottages and return their bobbins full of spun-thread at a price. ${ }^{11}$

Hardwicke Rawnsley's account maintains the division of intellectual labour that features in much of the Arts and Crafts movement's writing and practice, attributing the creative ideas to Ruskin, while classifying the women carrying out the actual work as his followers:

If the renewed industry was fortunate in having as its originator a man who was an idealist and could by his facile pen make its prospects known to the public [Ruskin], it was as fortunate in having a practical woman and a most self-sacrificing and indefatigable enthusiast for Ruskin's teaching at its head to carry out all the difficult detail of starting the workers and organising the industrial effort. No words of mine are needed to put on record what the Langdale Linen Industry owed in its first five years of uphill work to Miss Twelves. When she broke her connection with that neighbourhood and came across the Raise gap to Keswick, she was able to know that she had not only established the fact that hand-spun linen could be produced at a price which the public, and specifically the embroidering public, would pay for it, but she had seen enough of the pleasure brought into cottage homes by the humming wheel...12

The reference to 'the embroidering public' underscores that the middle-class female consumer was a driving force in this particular value chain. Reminiscent of how handmade cultural capital functions now, 'home work' in rural Victorian England competed against cheaper, mass-produced imported items using the cultural capital of unique handcrafted and ethically produced items. Supporters of the Arts and 
Crafts movement promoted the superiority in quality and taste of the handmade to the growing middle classes, while simultaneously targeting the newly opened-up tourist market that grew with the technological advances of the railway. The vanquishing of the 'tyranny of distance' by the railway, in its own ways a communications technology, parallels how digital technology in the present is opening up new markets by closing the distance between consumers and the homes of so-called amateur producers.

At a time of profound change in the material tangibility of production, and in a society swamped with mass-manufactured goods, the handmade offers a reprise, an alternative and an access to a world where technology takes the form of simple tools, and objects are understood as 'safe' and nostalgic. Similarly (and I would argue more importantly for the Etsy moment), handmade objects are imbrued with touch and therefore offer a sense of the 'authentic' in an inauthentic world. They offer connection to the maker through the skill and learning apparent in their construction and they demonstrate the time spent on their construction in a way in which other objects cannot.13

Joanne Turney in her work on knitting draws upon the work of feminist historian Leonore Davidoff who includes women's craft practice alongside farmhouse cookery, organic gardening and wine making as part of a larger contemporary emphasis on 'creative homemaking' as a 'suburban substitute for authenticity'.14 Certainly nostalgia and a focus on environmental issues in 'back to basics' lifestyles explain the resurgent interest in and demand for craft. However, in emphasising the renewed aura of the analogue, I would argue that it is not merely withdrawal into nostalgia or the nuclear family induced from a specific event such as 9/11 or the global financial crisis (GFC), but largely a response to a number of bigger, longer, economic, industrial and cultural shifts around the economic base model vis-a-vis production and manufacturing in particular. Growing awareness of the environmental and social costs of the circulation of cheap consumer goods is giving rise to concerns around large-scale industrialisation that are similar to those that gave rise to the Arts and Crafts movement. Both historical moments are looking to smaller scale, even domestic, models of handmade creativity as a desirable aesthetic antidote to these wider global problems: 
Today's craft is also about empowerment: feeling a sense of achievement when making something with your own hands. It's about taking a stand or making a statement against this modern, digital, disposable age of mass production and consumption that is leading the world into environmental and economic ruin. 15

By extension, consumption of such goods, along with farmers' markets and fair trade items, becomes part of a set of ethical and self-aware purchasing behaviours.

-THE RENAISSANCE IN WOMEN'S CRAFTS: ACTIVISM, AUSTERITY AND NOSTALGIA

It is not just so-called 'digital natives' who are embracing the materiality of the handmade, analogue artefact. With apologies for the pun, a number of threads can be identified as feeding into the renaissance of craft: a shift in the necessity and cultural acceptability of private cultures of austerity resulting from the GFC; nostalgia, including nostalgia for 'a more materially substantive past'; 16 concerted feminist and/or artist campaigns for recognition of the creative value of fibre arts in the face of its historical de-valuing as women's domestic, unpaid activity; ${ }^{17}$ the new networking, production and consumption affordances of the internet; ${ }^{18}$ and the rise of crafts-based activism. ${ }^{19}$

It is now well established that previously unfashionable women's crafts such as knitting and crochet have been stripped of their embarrassing 'nana' or even outright anti-feminist connotations, ${ }^{20}$ and in the noughties have became fashionable once more. ${ }^{21}$ Models and celebrities have been happily captured in candid moments knitting in the downtime between performances and runway turns. ${ }^{22}$ Demonstrating an interest in a wider craft aesthetic, others have donned high-end fashion labels' takes on traditional crafts, such as Cate Blanchett's much commented-upon crochetsquare 'blanket dress' worn in 2009 to a 'red carpet' event. ${ }^{23}$ This colourful assemblage bore more than a passing resemblance to the handmade crochet-square blankets to be found in charity shops around Australia. A number of factors have been identified as fuelling a renewed interest in craft, not the least of which is the presence of increasing numbers of women in the workplace, and many of these in increasingly well-paying jobs. Some 'time poor, cash rich' women find themselves with an increased capacity to engage in discretionary spending such as on handmade items, which once they may have made themselves. Others note the 
cyclical nature of revivals, including craft revivals, observing that the familiarity of styles, activities and ideas of the past are frequently looked to 'as a direct response to the contemporary world. At times of crisis, instability and anxiety, the past offers a sense of security otherwise absent', 24 and its styles are ripe for picking by a fashion system known for its repackaging of historical trends. A conservative nostalgia, linked to the nostalgic desire for retreat, emphasises security and the home, with a concurrent rise in interest in simple home cooking ('comfort food') and domestic crafts such as knitting and sewing. ${ }^{25}$

No practice better exemplifies the contemporary distinctly 'not your grandmother's crafts' than 'craftivism'. Of these activities, 'yarn bombing'-crochet and knitting-based 'graffiti'-is perhaps the most high profile. 'Merging the disciplines of installation art, needlework, and street art', and largely identified as having been started by Houston-based crew Knitta Please, yarn bombing consists of the clandestine act of fastening knitted or crocheted items to fixtures in public spaces. ${ }^{26}$ The acts encompass a vast range of talents and ideas, from humble multicoloured lines of plain knitting affixed around street signs or car aerials, through to much more complex and truly artistic installations that are custom-made to fit a complex item (see Figures 1 and 2). The guerrilla creativity manifest in yarn bombing represents a break from the placement of knitting and crochet within feminised domestic spaces, and instead deploys their quotidian softness for effect in mostly urban landscapes:

The unexpected nature of 'abandoned' knitting or crochet can be considered a defiant act in our ordered society. In this age of manufactured goods, handcrafted items are often considered cherished objects. By leaving pieces on the street, yarn bombing becomes a wonderful and unexpected form of anarchy ... Because knitted and crocheted designs are intrinsically homey, using yarn craft in unconventional ways can have a special kind of resonance. ${ }^{27}$

In their book on yarn bombing, Moore and Prain reinforce the participant's desire to 'take back the knit' and identify craftivism as a stand against the values of corporate consumerism and mass-produced goods. ${ }^{28}$ But craftivism is also part of a wider trend to distance craft practice from accusations of conservatism. 

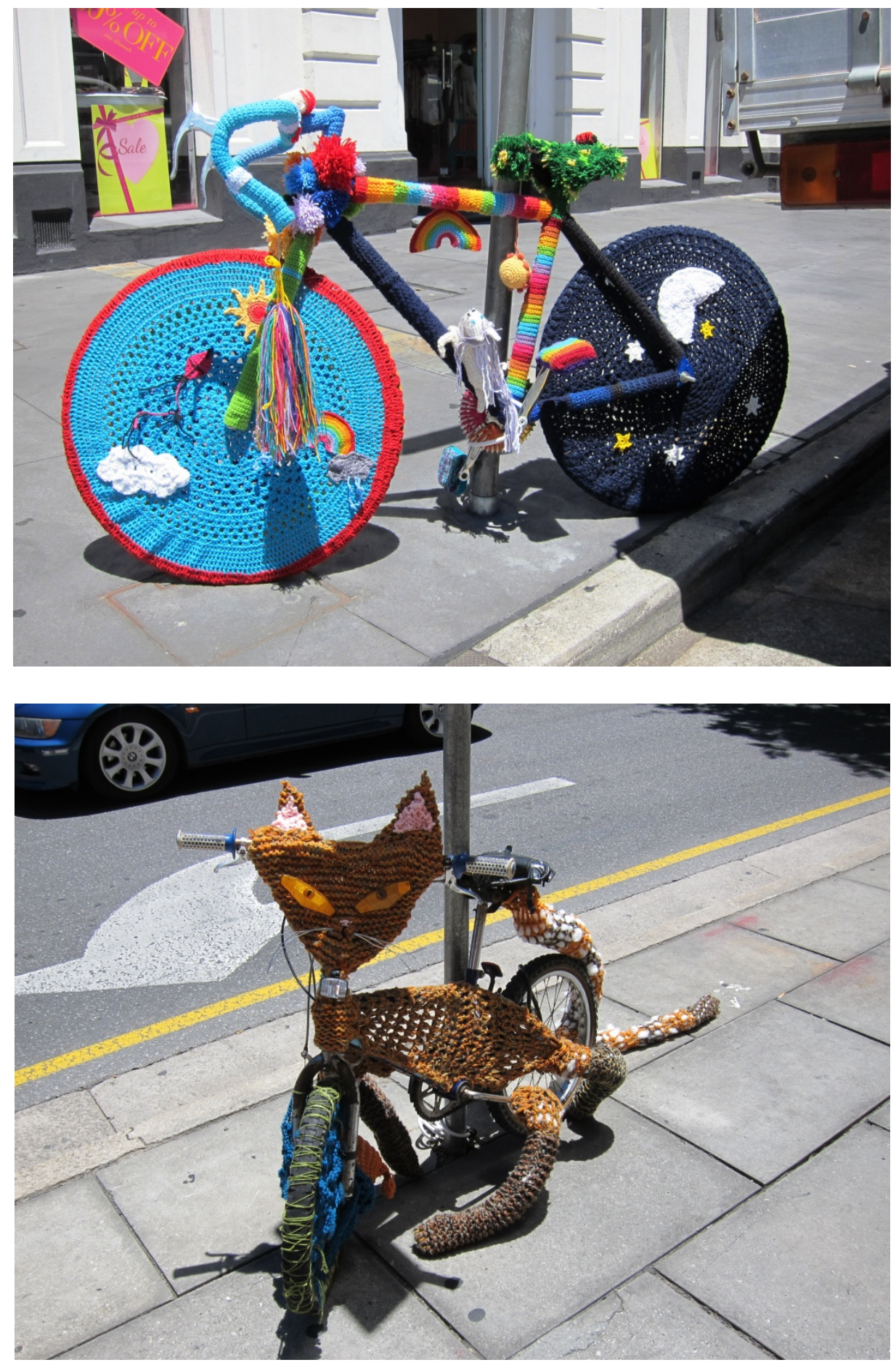

Figures 1 \& 2: Yarn bombing street art, Rundle Street, Adelaide, January 2012 (Photographs: Susan Luckman) 
Indeed, crafting is a complex phenomenon in terms of cultural location, class and gender, as is clearly evident in the online comments posted in response to the July 2011 Guardian article 'Pride in the Wool: The Rise of Knitting', where a stream developed debating the status of knitting as a desirable activity beyond 'east London hipsters who knit in pubs or on the tube':

'you'll more likely have acrylic ... and even that is pricey, far cheaper to buy ready made clothes. knitting is something you don't see around here, another trend that stops at watford (when I revealed to friends I made all my own christmas cards they told me they didn't realise money was that tight, and when I said its [sic] because I like doing it, they found it highly amusing'

'@ajchm plenty of knitters in the Midlands and that's north of Watford!'

'Agree that it is definitely more expensive than buying ready-made clothes, but a lot more fun plus you get to customise and have something no one else has got :-)'

'I certainly don't think knitting is confined to hipsters. I lived in Leeds for 8 years and attended a knitting group who would make knitted breasts for breast cancer charities, or knitted mice for local cat sanctuaries, and everyone there was predominantly at least a little bit goth or alternative and under 30 and queer.' 29

Contemporary fabric and yarn-based crafts can be both a cost-saving or recycling activity as well as a high-end leisure pursuit. Thrift store finds and redundant garments can be reworked; alternatively, new materials can be purchased from high-end epicurean craft stores. While women's craft activities have a historical association with the austerity practice 'make do and mend', which given the current global financial crisis offers another possible reason for the resurgence of interest, crafting can also be an expensive and leisured practice. ${ }^{30}$ There is no 'one-size-fits-all' reason for people's engagement with craftwork. As sociologist Richard Sennett recently observed, words like 'creativity' carry a lot of class baggage. The working class have always been DIY, and for some, making one's own garments and other items is still indicative of being down at heel. ${ }^{31}$ 


\section{—CONTEMPORARY INTERNET-ENABLED PRACTICES OF PRO-AM PRODUCTION}

But it is not just self-identified knitting and crochet activists who see the handmade as a valuable counterpoint to all the mass-produced 'stuff' available for consumption in the industrialised world. ${ }^{32}$ With due optimism David Gauntlett, in his book Making is Connecting, identifies the exponential growth of online communities of makingboth of digital and 'analogue' (for example craft) things-as one of the wonderfully productive outcomes of the shift from a "sit back and be told" culture towards more of a "making and doing" culture' enabled by Web 2.0 technologies. ${ }^{33}$ For Gauntlett, the internet is key to understanding the take-off of contemporary DIY craft cultures, just as understanding the joys implicit in creativity of all kinds is key to the success of digital creativity in the post-Web 2.0 online environment. In particular, he argues that the internet has provided renewed impetus to analogue craft communities by furnishing them with a tool to provide renewed visibility to craft practices, not to mention that the internet allows for the networking of 'excited enthusiasts in one corner of the world to inspire and encourage similarly energized individuals elsewhere, with a depth and speed not previously possible'. ${ }^{34}$ He singles out Etsy and knitting social network Ravelry as key players in this international web of crafters. 35 These two sites exemplify the community-building capacities of the internet, and more importantly within the context of this article, its ability to render international marketing and distribution networks accessible to sole traders and micro-enterprises. In turn, the capacity afforded by the internet to so easily find, even across oceans, small-scale producers has driven the demand for the products of these business operators. ${ }^{36}$

As I have written elsewhere, the democratisation of access to digital media tools and the development of networked user-generated content online are signalling a shift in internet usage towards an environment in which the distinction between producer and consumer is less clearly defined. ${ }^{37} \mathrm{~A}$ substantial body of innovative academic writing has engaged with the new economic models developed to account for 'convergence cultures' including the hybrid producer-consumer 'prosumer' relationship. ${ }^{38}$ However, there has been less examination of the impact of this upon craft practice, and upon the traditional divides between craft and art, and amateur and professional. 39 
Online design craft distribution after Etsy is an outstanding example of the potential of the internet to operate as a 'long tail' distributor. As Chris Anderson writes:

Our culture and economy are increasingly shifting away from a focus on a relatively small number of hits (mainstream products and markets) at the head of the demand curve, and moving toward a huge number of niches in the tail. In an era without the constraints of limited shelf space and other bottlenecks of distribution, narrowly targeted goods and services can be as economically viable as mainstream fare. 40

A marketplace such as Etsy profoundly complicates how we think about craft-based activity in terms of amateur versus professional divisions, because while all makers on Etsy are seeking to be paid for their work, the level of turnover of, and therefore income derived from, the activity can vary greatly. Some makers may be occasional sellers of small-profit items, while others may be deriving a full-time income not only for themselves but for other employees from their virtual shopfront. Therefore amateur-professional divisions based on being paid or not being paid for your labour have limited practicality here. Likewise, there is no gate-keeping around formal training as a condition of access to Etsy. This inclusiveness potentially valorises the frequently undervalued informal acquisition and passing on of skill sets that often underpin and inform the expertise of craft. As feminists (among others) have been strongly arguing for at least the last half century, whether an activity counts as amateur or professional, craft or art, is highly gendered, raced and generally Othered-'it is no accident that the work of marginalized groups often counts as craft'41-yet here the only limits to involvement are a product to sell and the capacity (technical, linguistic and financial) to set up an online shopfront. Given the complexities outlined above, rather than thinking about craft post-Etsy as a manifestation of an amateur or a professional economy per se, we might be better re-imagining a more fluid spectrum of 'pro-am' activity.

-THE ETSY ECONOMY: ONLINE, MARKET-BASED DESIGNER CRAFT ENTREPRENEURIALISM

Show me a crafter without a website, and I'll show you a crafter who will probably have a website within six months. 42 
Indie or alternative DIY craft fairs and online marketplaces such as Etsy explicitly set out to distance themselves from their more 'twee' forebears: 'there aren't any country cottages, cottage gardens or cutesy animals here, unless with a twist or a heavy dose of irony'.43 Indie craft also overlaps with art practice ('craft-art') and artists whose medium may be 'craft-based' but destined for the gallery, again challenging traditional divisions between amateur (women's) and professional creative production. Indie craft is underpinned by a stripped-back value chain-that is, the satisfaction of buying direct from the artist that made the work-and thus can claim to be ethical and local. ${ }^{44}$ Design craft markets and Etsy-style online distribution sites are sites where women's small-scale creative economic activity, frequently conceived as amateur production, is welcome, much as, Lippard writes, the 'gift shoppe ... country arts fair and outdoor art show circuit' have been open to women in ways the high art world has not been. ${ }^{45}$ While more men may be getting involved, indie craft remains overwhelmingly a female activity. 46

In another parallel with the Arts and Crafts movement, Etsy was conceived in 2005 by a male internet start-up team, Rob Kalin, Chris Maguire and Haim Schoppik, working in conjunction with Jean Railla from the Get Crafty website. It was backed by considerable start-up venture capital and its advisory board included high-profile figures from some of the most successful internet start-ups such as Caterina Fake, co-founder of Flickr, and Albert Wenger, former president of Delicious. ${ }^{47}$ By contrast, approximately 95 per cent of the sellers were women and, according to Kalin, 'mostly stay-at-home moms and college students looking to supplement their income rather than make a full-time living'.48 The average age of Etsy sellers was thirty-four years, a time of life when many of these largely tertiary-educated women would have young children to care for. ${ }^{49}$ Unlike other online sites (such as eBay), Etsy does not rely upon selling advertising space to external parties on its notably uncluttered web interface. Rather, its business model relies upon the successful sales of its creator members; setting up a shopfront is free, but Etsy charge twenty US cents for each item listed and take a commission of 3.5 per cent of each sale. ${ }^{50} \mathrm{In}$ keeping with the emphasis on an ethical, personal economy where the provenance of the item is clear and bought 'directly' from the maker, makers on Etsy set up the virtual shopfront themselves and feature a personal profile page. 


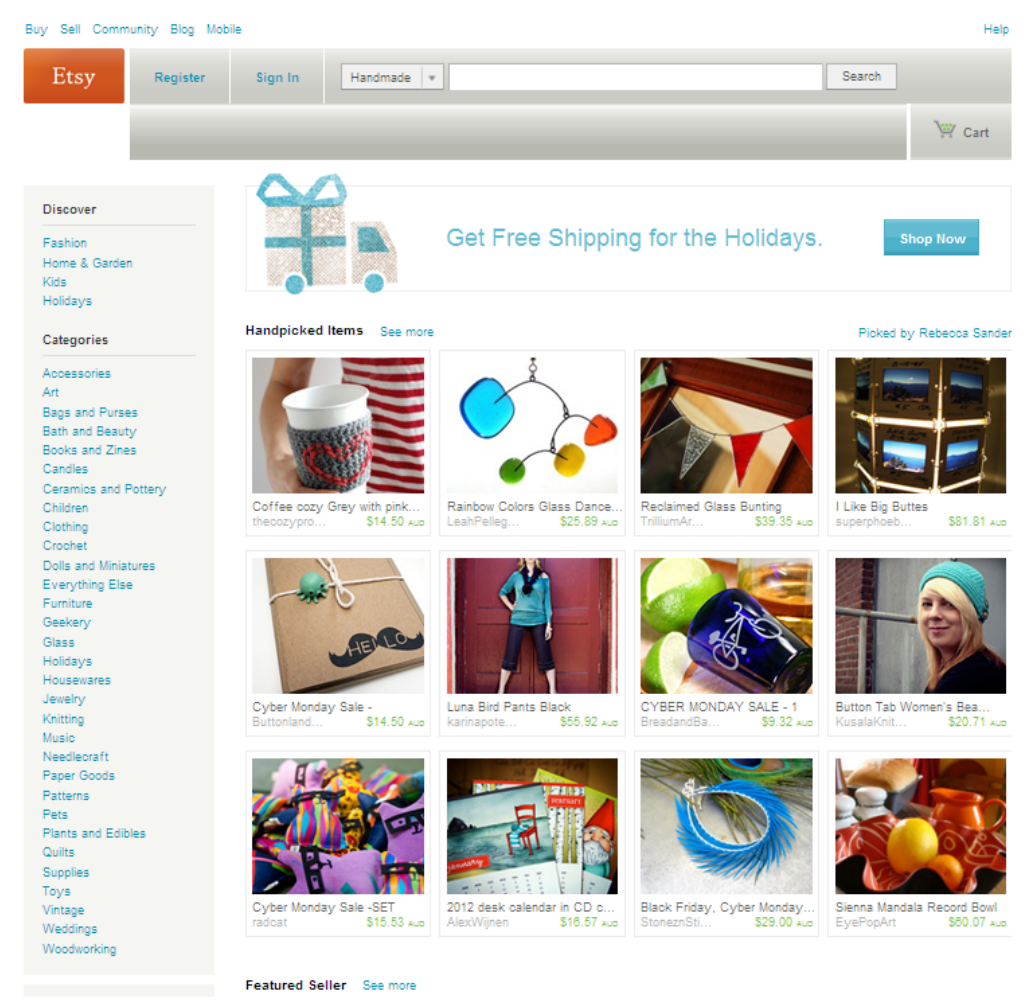

Figure 3: Etsy website, 30 November 2011

As a global shopfront with high visibility, Etsy challenges conservative visions of women's craft activity as an 'invisible' and 'mute' activity undertaken in the home and thus outside the larger commercial economy. It also challenges traditional constructions of women's (fabric and yarn-focused) domestic money-making 'hobbies' as purely amateur creative production. ${ }^{51}$ Craft entrepreneurialism is more than 'an extension of thrifty housewifery and of "making do" removed from the sphere of the monetary marketplace'.52 Rather, it is precisely the kind of pro-am creative entrepreneurialism enabled by the social and economic expansion of the internet. The women featured on Etsy and in the pages of books such as Levine and Heimerl's Handmade Nation are running serious small business operations. ${ }^{33}$ No longer relegated to a corner of shared family space or the dining table in between family meals, these women are frequently photographed in their home studio, whole rooms set aside to conduct their creative business. Also evident in the interviews is that many of these US-based women are making more than 'pin money' from their work. ${ }^{44}$ For many contemporary makers this revenue is additional to other income, 
for others online craft entrepreneurialism is far more than supplementary to other household revenue streams: 'When I moved back to San Francisco and I couldn't find a job, I just created my own website and made my own job selling those things'.55 Further:

I am driven by the ideal of supporting my family and myself through craft ... My generation of craftspeople is being revered in craft books, while new craft fairs and markets are springing up across the nation. With all these optimistic advances, I'm positive I can make it work. This year I gave birth to a marvellous son, Caspian. Like many crafty moms, I am trying to balance my child and my business, while both are growing. Making a living from my craft has always been my motivation to keep sewing. ${ }^{56}$

A sympathetic home environment and other income sources also differentially underpin producers at different stages of their career and fluctuating economic cycles: 'I have a very supportive family and husband, so it works out well. We have pretty much everything we need. We are not rolling in it; I am never going to get rich doing this. But I am happier than I have ever been in my life, so it is definitely worth it.' 57 For others, popularity has its own issues as scaling up to meet demand as a sole trader and maker is not easy. Some people simply set limits to when they are 'open' and how many items are available; others have to engage in the process of setting themselves up as an employer with all the practical and ethical issues to which this gives rise. ${ }^{58}$

But, in political terms, is this pro-am creative economy radically empowering? At a personal level, being able to work from home and/or flexibly has been embraced by many women in particular as an important compromise between paid work and unpaid domestic responsibilities. The very taken-for-grantedness of communications and other digital technologies as quotidian devices sees them playing a determining role in normalising the home office and home studio. Working from home is an attractive option for women accustomed to paid work, but now also finding themselves with caring responsibilities within the household. As more women in the global West graduate from higher education and/or have a career outside the home before or while having children, the networked home is becoming a normalised paid work location. ${ }^{99}$ This is no huge leap in many ways for women, for while Sennett, quoting Adam Smith, notes the 'separation of home and labor is ... the 
most important of all the modern divisions of labour', feminists have long challenged the invisibility of women's labour which allows for the construction of divisions such as this. ${ }^{60}$ Distribution and marketing sites such as Etsy can therefore slot easily into this existing environment, and via the handmade continue the long, but previously less visible, tradition of middle-class women using their creative skills to contribute from home to the family income.61

The Arts and Crafts movement created middle-class desire for artisanal working-class and rural skills as a response to the later stages of Industrial Revolution. Today, when direct connections to the hands that produced the goods we own are rare, an abundance of mass-produced goods reinstates a Benjaminian aura to the analogue and the handmade. The ironic upshot of this is that women's production, frequently existing at the margins of desirability and only called on in times of economic vulnerability and austerity, is now in mainstream demand, fuelled by middle-class women who have the available income to make discretionary purchases from sites such as Etsy, and who are picking up needles themselves.

Like the countercultures of the 1960s and 1970s, indie craft sold at markets and through Etsy-style distribution networks is positioned as an alternative to mainstream consumer culture.62 Mainstream acceptance and middle-class respectability of such products reflects a wider shift among sections of the global West towards ethical consumption and environmental awareness, rather than a necessarily more conservative agenda on the part of indie craft participants and buyers. A DIY economic-aesthetic shift around women's crafts upholds the motto the 'personal is political', which via sites like Etsy is able to mix the romantic and utopian vision of the handmade with the very real necessity of income generationeven if it is for many a top-up, not their main source of income. But it is still fundamentally a consumption-oriented response; a way to ameliorate rather than stop further environmental damage or undo that already done. This can be seen especially in the emphasis on ethical gift buying as a marketing strategy around Christmas, and in many of the goods for sale being decorative as distinct from necessary to everyday living. ${ }^{63}$ Like farmers' markets and their emphasis on the lack of distance-literal and figurative-of the product from the end-point consumer in the production value chain, Etsy can be dismissed as the heroic 'can do' of the middle classes purchasing products they can 'feel good' about.64 Or, following 
Bakhtin's work on the carnivalesque, more politically as a kind of consumer safety valve releasing anger at the status quo and/or quenching the desire for 'genuine' change.65 As Kirsty Robertson has observed more specifically in relation to craftivism: 'the resurgence of "feminine" knitting [and, arguably therefore, other women's craft-based practices] is in fact much more intertwined with the changing "masculine" economy than either those detracting from or supporting knitting as radical might be willing to admit'.66 Certainly with its origins in venture capital, similar arguments can easily be made regarding Etsy. More problematically, not only is Indie craft and the post-Etsy economy the domain of mostly middle-class women, in the United States at least it is also disproportionately, and frequently uncritically, almost exclusively white. ${ }^{67}$

As a flexible, frequently home-based workplace production economy, the Etsy and indie craft work models resonate with wider debates about engaging in selfactualising cultural work within the creative economy, and how these engagements are enabled by digital technology. Such work practices might be particularly attractive to women, as they allow for income generating work to be conducted alongside unpaid, domestic responsibilities, but they can also lead to a 'presence bleed' whereby the worlds of paid work, domestic labour and leisure blur, normally at the expense of the latter.68 While self-fulfilment, autonomy and flexibility have been identified as key reasons people undertake self-employed, pro-am work from home, it is important to note that research suggests it does little to shift traditional gender divisions within the household.69 Conversely, few of us, even in affluent countries, are controllers of the larger means of production-that is, owners of significant global capital-and are hence are not in a position to directly bring about large-scale and immediate change. I certainly do not wish to uncritically celebrate alternative consumerism as the way forward to a radically different future, but an examination of the production and distribution side of the post-Etsy marketplace gives rise to interesting questions and possibilities in terms of desirable future hybrid professional-amateur economies. 
Susan Luckman is Associate Head of School: Research of the School of Communication, International Studies and Languages at the University of South Australia where she is also an associate professor. She teaches and researches in the fields of media and cultural studies. She is a foundation member of the ARC Cultural Research Network, author of the forthcoming book Locating Cultural Work: The Politics and Poetics of Rural, Regional and Remote Creativity and numerous book chapters, peer-reviewed journal articles and government reports on creative cultures and industries. She has co-edited an anthology on creative music cultures and the global economy titled Sonic Synergies (2008).

\footnotetext{
-NOTES

1 http://www.etsy.com/; http://www.cathkidston.co.uk/default.aspx. See also:

<https://www.ravelry.com/>; <http://www.knitty.com/ISSUEdf11/index.php>;

$<$ http://buyhandmade.com/>; <http://www.craftster.org/>; <http://www.ministryofcraft.co.uk/>.

2 Theodor Adorno, The Culture Industry: Selected Essays on Mass Culture, Routledge, London, 2001;

Theodor Adorno and Max Horkheimer, Dialectic of Enlightenment, trans. John Cumming, Allen Lane, London, 1973; Walter Benjamin, 'The Work of Art in the Age of Mechanical Reproduction',

Illuminations, Harcourt, Brace and World, London, 1968, pp. 211-44. This return to the desirability of the analogue ironic, at least with regards to the reproduction of music, especially jazz, which so concerned Adorno and Horkheimer in the Dialectic of Enlightenment. A keen interest in the unique qualities of the analogue has for a couple of decades now been present in music connoisseurship cultures where vinyl and the turntable remain valued items in the otherwise digital economy of recorded music. See for example Rebekah Farrugia and Thomas Swiss, "Tracking the DJs: Vinyl Records, Work, and the Debate over New Technologies', Journal of Popular Music Studies, vol. 17, no. 1, 2005, pp. $30-44$.

3 Tonya Jameson quoted in Robertson, p. 191.

4 Fiona Hackney, “'Use Your Hands For Happiness”: Home Craft and Make-do-and-Mend in British Women's Magazines in the 1920s and 1930s', Journal of Design History, vol. 19, no. 1, p. 23.

${ }^{5}$ Alan Crawford, C.R. Ashbee: Architect, Designer and Romantic Socialist, Yale University Press, New Haven, CT, 2005; Sara E. Haslam, John Ruskin and the Lakeland Arts Revival, 1880-1920, Whitchurch, Merton Priory Press, 2004; Fiona MacCarthy, The Simple Life: C.R. Ashbee in the Cotswolds, Faber and Faber, London, 2009; Joanne Turney, The Culture of Knitting, Berg, Oxford, 2009.

6 MacCarthy, p. 10.

7 Ibid.
} 
${ }^{8}$ Haslam; H.D. Rawnsley, Ruskin and the English Lakes, James MacLehose and Sons, Glasgow, 1902 (republished on demand by Bibliolife).

As MacCarthy acknowledges in her biography of Ashbee, ultimately the interests of the almost exclusively male guild workers came first, and, as such, 'did not always accord well with married life' (p. 129). Further, she goes on to note that even in the socialist idealist circles of the Arts and Crafts movement, for men to treat their wife as an equal was 'rare' (p. 132). In terms of their creative input: 'Arts and Crafts wives were very often relegated to embroidering cushion covers and illuminating manuscripts' (p. 132). The reification of the limited value of women as creators which relegated them to the lighter 'decorative' work 'beautifying' the items created by men is repeated across the British Arts and Crafts movement, notably in the Staffordshire ceramics industry where women famously in the case of people like Susie Cooper, did the painting, but were not the ceramicist per se. This was not the case across the Atlantic, where American women established independent studios where they were free to pursue their own creative interest in production:

The Arts and Crafts movement led to new opportunities for women; for example, Robineau, Perry and Elizabeth Overbeck all studied at Alfred with the most revered ceramics instructor in America, Charles Fergus Binns. However, opportunities were limited by old stereotypes. Women were either confined to traditionally 'feminine' crafts, such as textile production, or to those branches of craft activity thought appropriate for the 'weaker sex'. A rigid sexual division of labour prevailed in the ceramics' industry: men threw the pots and fired the kilns while women did the decorating. Only by working in their own shops were women able to pursue careers as potters, metalsmiths and bookbinders. See Elizabeth Cumming and Wendy Kaplan, The Arts and Crafts Movement, Thames and Hudson, London, 1991, p. 129.

${ }_{9}$ Cumming and Kaplan.

10 Stella Minahan and Julie Wolfram Cox, 'Stitchn Bitch: Cyberfeminism, a Third Place and the New Materiality', Journal of Material Culture, vol. 12, no. 1, 2007, pp. 5-21; Turney. 'Such was the employment that prevailed in the pastoral dales. Where wool was not at hand in the small rural towns, the wheel for spinning flax was almost in constant use, if knitting was not preferred, which latter occupation has the advantage (in some cases disadvantage) that not being from necessity stationary, it allowed of gossiping about from house to house, which good wives reckoned an idle thing.' Ruskin quoted in Rawnsley, p. 132.

11 Rawnsley, pp. 139-40.

12 Ibid., pp. 142-3.

13 Turney, p. 80.

14 Ibid., p. 181.

${ }^{15}$ Jo Waterhouse, Indie Craft, Laurence King, London, 2010 p. 10.

16 Minahan and Wolfram Cox, p. 14; See also Turney. 
17 Clive Edwards, “Home is Where the Art Is": Women, Handicrafts and Home Improvements 17501900', Journal of Design History, vol. 19, no. 1, pp. 11-21; Lucy Lippard, 'Making Something From Nothing (Toward A Definition of Women's “Hobby Art”)' in The Craft Reader, ed. Glenn Adamson, Berg, Oxford and New York, 2010, pp. 483-90; Rozsika Parker, The Subversive Stitch: Embroidery and the Making of the Feminine, The Women's Press, London, 1984.

18 Kirsty Robertson, 'Rebellious Doilies and Subversive Stitches: Writing A Craftivist History' in Extra/Ordinary: Craft and Contemporary Art, ed. Maria Elena Buszek, Duke University Press, Durham and London, 2011, p. 190

19 Jack Bratich and Heidi Brush, 'Fabricating Activism: Craft-Work, Popular Culture, Gender', Utopian Studies, vol. 22, no. 2, 2011, pp. 233-60; Otto von Busch, 'Exploring Net Political Craft: From Collective to Connective', Craft Research, vol. 1, 2010, pp. 113-24; Maria Elena Buszek (ed.), Extra/Ordinary: Craft and Contemporary Art, Duke University Press, Durham and London, 2011; Mandy Moore and Leanne Prain, Yarn Bombing: The Art of Crochet and Knit Graffiti, Arsenal Pulp Press, Vancouver, 2009, p. 17.

${ }^{20}$ Lippard; Parker; Turney.

21 Perri Lewis, 'Pride in the Wool: The Rise of Knitting', Guardian, 6 July 2011,

<http://www.guardian.co.uk/lifeandstyle/2011/jul/06/wool-rise-knitting>; Turney; Anna Vlach, 'Handmade is Cool Again', Advertiser, 12 November 2011, p. 51; Walker, Rob, 'Handmade 2.0', New York Times, 16 December 2007.

22 Bratich and Brush; Minahan and Wolfram Cox, p. 16; Turney, p. 103; von Busch, p. 114.

${ }^{23}$ See <http://www.news.com.au/entertainment/fashion/cate-blanchett-wears-crochet-dress-on-redcarpet/story-e6frfn7i-1225776287036>.

24 Turney, p. 53.

25 Faythe Levine and Cortney Heimerl, Handmade Nation: The Rise of DIY, Art, Craft, and Design,

Princeton Architectural Press, New York, 2008; Minahan and Wolfram Cox.

26 Moore and Prain, p. 17.

27 Ibid., pp. 22-3.

28 Ibid., p. 22.

${ }^{29}$ Lewis.

${ }^{30}$ David Gauntlett, Making is Connecting: The Social Meaning of Creativity, from DiY and Knitting to YouTube and Web 2.0, Polity, Cambridge, MA, 2011; Parker; Turney; Waterhouse; Vlach.

31 BBC Radio 4, 'Craft and Community', Thinking Allowed, 2 May 2011,

<http://www.bbc.co.uk/programmes/b010mrzc>.

32 Louise Mazanti, 'Super-Objects: Craft as an Aesthetic Position', in Extra/Ordinary: Craft and

Contemporary Art, ed. Maria Elena Buszek, Duke University Press, Durham and London, 2011, p. 60.

33 Gauntlett, p. 8.

34 Ibid., p. 62.

35 Ibid., p. 68. 
36 Nancy Jurik, 'Getting Away and Getting By: The Experiences of Self-Employed Homeworkers', Work and Occupations, vol. 25, no. 7, 1998, p. 9.

37 Julie de Roeper and Susan Luckman, 'Future Audiences for Australian Stories: Industry Responses in a Post-Web 2.0 World', Media International Australia, no. 130, 2009, pp. 5-16.

${ }^{38}$ Henry Jenkins, Convergence Culture: Where Old and New Media Collide, New York University Press, New York, 2006. Chris Anderson, The Long Tail: How Endless Choice is Creating Unlimited Demand, Random House, London, 2007; Don Tappscott and Anthony Williams, Wikinonomics: How Mass Collaboration Changes Everything, Penguin, New York, 2006. For the 'prosumer relationship, see Axel Bruns, Blogs, Wikipedia, Second Life and Beyond: From Production to Produsage, Peter Lang, New York, 2008.

39 This has been examined in more detail with relation to design. See, for example, Gerry Beegan and Paul Atkinson, 'Professionalism, Amateurism and the Boundaries of Design', Journal of Design History, vol. 21, no. 4, 2008, pp. 305-13; Gregory Turner-Rahman, 'Parallel Practices and the Dialectics of Open Creative Production', Journal of Design History, vol. 21, no. 4, 2008, pp. 371-86; Bas Van Abel, Lucas Evers, Roel Klaassen, Peter Troxler, Open Design Now: Why Design Cannot Remain Exclusive, BIS Publishers, Premsela, 2011.

${ }^{40}$ Anderson, p. 52.

41 Markowitz quoted in Stella Minahan and Julie Wolfram Cox, p. 12; see also Parker.

42 Levine and Heimerl, p. 35.

43 Waterhouse, p. 8. See, for example, <http://www.renegadecraft.com/>;

<http://www.bowerbirdbazaar.com.au/>; <http://www.bazaarbizarre.org/>;

http://www.thegirlieshow.net/; < http://urbancraftuprising.com/>.

44 Levine and Heimerl, p. ix.

${ }^{45}$ Lippard.

46 For their book Handmade Nation, Levine and Heimerl interviewed over eighty people from the scene; 95 per cent were women (p. x).

${ }^{47}$ Kerry Miller, 'Etsy: A Site for Artisans Takes Off', Bloomsberg Businessweek, 12 June 2007, <http://www.businessweek.com/print/smallbiz/content/jun2007/sb20070611_488723.htm>.

48 Ibid.

49 Walker.

$50<$ http://www.etsy.com/sell/fees>.

51 Cumming and Kaplan; Turney.

52 Turney, p. 9; see also Parker.

53 Levine and Heimerl.

54 Turney, p. 179.

55 Jill Bliss, quoted in Levine and Heimerl, p. 128.

${ }^{56}$ Clarity Miller, quoted in Levine and Heimerl, p. 140. 
57 Emily Kircher, quoted in Levine and Heimerl, p. 66.

58 Walker.

59 'When I first started my website, I had just had my youngest son. I thought I was just going to set up the site for fun so I could have a place to post what I made. I wasn't selling a lot then. I sold on consignment through one local store. I decided that a website would be kind of fun, and then people started to buy things. So I started selling and it all got bigger form there. I began noticing other websites that were starting up and selling things. It was just kind of like a happy accident. My Paper Crane was for fun, and it turned into a big business.' Pennsylvania-based Heidi Henney, quoted in Levine and Heimerl, p. 16.

60 Richard Sennett, The Corrosion of Character: The Personal Consequences of Work in the New Capitalism, W.W. Norton \& Company, New York, 1998, p. 36.

61 Turney.

62 Levine and Heimerl; Turney.

63 Walker; see also the umbrella website <http://buyhandmade.org/>.

64 Levine and Heimerl.

65 Mikhail Bakhtin, Rabelais and His World, trans. Helene Iswolsky, MIT Press, Cambridge, MA, 1968.

66 Robertson, p. 192.

${ }^{67}$ It's important to acknowledge that Dawkins' research revealed not only a lack of concern for racial inclusion among some of the local craft fair organisers she spoke to, but also revealed a much more disturbing policing of racial exclusion via monitoring of what kind of stalls are allowed. In the words of one of the Detroit Urban Craft Fair organisers, 'their [black crafters'] aesthetic doesn't fit in', Dawkins, p. 268.

68 Jurik; Melissa Gregg, Work's Intimacy, Polity Press, Cambridge, 2011.

${ }^{69}$ Jurik. 